\title{
Construction of a Strategic Business Process Reengineering Model: Empirical Research on the After-sale Service Process of SH
}

\author{
An-Shin Shia ${ }^{1}$, Bau-Jung Chang ${ }^{2}$ \\ ${ }^{1} \mathrm{PhD}$ candidate, $\mathrm{PhD}$ Program in Business, Feng Chia University, Taiwan \\ ${ }^{2}$ Assistant Professor, Department of Business Administration, Feng Chia University, Taiwan \\ Correspondence: An-Shin Shia, PhD Program in Business, Feng Chia University, Taiwan.
}

\author{
Received: May 9, 2017 \\ Accepted: June 8, 2017 \\ Online Published: June 19, 2017 \\ doi:10.5539/ibr.v10n7p67 \\ URL: https://doi.org/10.5539/ibr.v10n7p67
}

\begin{abstract}
For the past decade, business process reengineering (BPR) has gradually evolved from a revolutionary principle, which provided enterprises with methods to eliminate problems, into a set of management approaches for enterprises to face unpredictable and uncontrollable circumstances. This study puts forward an integrated model, strategic business process reengineering model,, which focuses on analysis of the three stages of BPR, and explores how BPR develops into competitive advantage with strategic basic factors - positioning, unique activities, trade-offs and fit. The authors undertake SH, a famous Tai wanese brand of small appliance, for case study and analysis. The research results show that the process reengineering activities held after strategic positioning should be improved through unique activities and trade-offs, such as technology-oriented, cross-departmental labor integration and trade-offs, cross-departmental rotation and talent cultivation, and cross-organizational support for channel manufacturers in their training of technicians. During the activities, mutual fit would lead to a set of behavior system, where construction plays an essential role, as it is difficult to imitate in competitive advantage.
\end{abstract}

Keywords: process reengineering, strategic positioning, competitive advantage, participation-styled observation, small appliance industry

\section{Introduction}

Enterprises adopting process reengineering is an international phenomenon that has grown rapidly in the past decade (Hammer, Hershman \& Wilson, 2010). Enterprise process management must be comprehensive, and enterprise process reengineering (BPR) promotes implementation methods designed to achieve significantly enhanced effects (Tenne \& DeToro, 1997). During certain periods, enterprises c an make great improvements and progress in their processes (Frank, 2006), while reducing customers' complaints, reaction time, response errors, and production and service time (Tai \& Huang, 2007). Moreover, process reengineering makes enterprises more adaptable to the future space of survival and de velopment (Champy, 1995). According to the investigation of Deloitte from 1995 to 1999, about 70\% of big wholesalersies in North America and Europe intentionally or unintentionally promoted BRP. Therefore, BPR is regarded as an approach for enterprises to address problems (Hammer et al, 2010) and a key to maintain a vigorous and sustainable enterprise (Hammer, 1990).

Nevertheless, some scholars believed that the success rate of process reengineering, as proposed by Hammer and Champy (1993), was lower than 50\% (McNurlin \& Sprague, 1998). Many empirical researches showed that enterprises often adopt the labor reduction measures of BPR to improve themselves and regain/enhance organizational functions. However, after labor reduction, the remaining employees are still in an unstable situation, which lowers work efficiency, results in the loss of core employees, and leads to an in adequate number of employees for organizational operation (McKinley, Sanchez \& Schick,1995; Shah, 2000); worse still, it influences the learning network, learning ability, and innovation of the organization (Fisher \& White, 2000; Cascio, 2002). Meanwhile, in the process of labor reduction, $74 \%$ of senior managers noticed large negative influence, including demoralization and decline in trust and productivity, and found that labor reduction had negative influence on the performance of many enterprises (Chen and Hsia, 2001). Moreover, layoffs affect a large number of families, to result in social unrest (Sun, 1994; Mckee Ryan \& Kinicki, 2002). This shows that there are still many problems in the implementation of BPR, which aims to address problems and create competitive advantages. Porter (1996), a strategy master, also pointed out that BPR can significantly improve the 
efficiency of an organization, and only by adopting strategic positioning can an enterprise maintain or enhance its competitive advantages. Thus, how to create competitive advantages from the strategic positioning of a command elevation point to process reengineering in detail is an issue that has never been studied to date. For that reason, the author proposes the strategic process reengineering model, integrates strategic positioning with BPR, and delves into the development of SH, a Taiwanese company of small appliances as the case study.

Established in 1981, SUNHOW appliance marketing company (SH) is the subject of discussion in this study. It's belongs to the small Household Electrical Appliance Manufacturing Industry (small appliance). The "small appliance" of SH include electronic pots, dish driers, juicers, electric fans, hair dryers, ovens, electric irons, microwave ovens, soybean milk machines, and coffee makers. Professional and famous Taiwan manufacturers or brands include Sunpentown (STP), TCY, Jyebao (JB), Jinkon (JK), and Supa fine (SF) (Baidu Data Research Center, 2017). Although appliances can be classified into large and small appliances according to their size and electricity consumption, most research in the academic community of Taiwan concentrates on the appliance industry (Large and small appliance) (Tsai, 2004; Chang, 2005; Chuang, 2009; Chen, 2010; Chen, 2012). Small appliance are daily necessities of all families, but they are often neglected by researchers in academic circles because of their ordinariness, which is why the author has chosen to study the small appliance industry. With emphasis on the small appliance industry, this study discusses $\mathrm{SH}$, a famous and representative manufacturer in the small appliance industry of Taiwan, and conducts interviews with the peer managers of various professional manufacturers and brands, such as STP, TCY, JB, JK, and SF, in order to collect information for comparative analysis.

Due to the impact of an unfavorable environment in recent years, about 50,000 small and medium enterprises in Tai wan have gone bankrupt since the 2008 financial tsunami in the US, including 3,567 factories and 43,936 companies (Tan, 2008). The scale of the European debt crisis, which erupted less than three years ago, is 12 times greater than that of the financial tsunami. If the crisis is not mitigated, its influence will be far greater than that of the financial tsunami (Chang, 2011). Under the impact of such an unfavorable environment, professional small appliance manufacturers of small and medium enterprises adopted BPR by reducing employees and salaries, and offering no-salary vacations to survive. During the period, most manufacturers cancelled their after-sale service departments and implemented various strategies, such as outsourcing and process reengineering, to respond to the crisis; nonetheless, the small appliance industry is changing. The fact that only $\mathrm{SH}$ adopted process reengineering without reducing employees, and integrated strategic positioning with BPR is an issue worthy of discussion.

The case study of SH incorporates unique activities into BPR and constructs the cross-departmental mutual support process, which significantly reduces the costs caused by the idle time of the departments, and thus, undertakes organizational reform without employee reduction. Cross-departmental work rotation refers to the position transfer of employees among different departments of the organization during a period of time (Bennett, 2003). Through such work rotation, employees can familiarize themselves with the works of the different departments/positions of the company, meaning they can have more efficient communication when collaboration among different positions and departments is required. The scale of position, the planning of a rotation route, and the professionalism and complexity of the works - are all factors that must be considered in rotation. As different units are involved in rotation, the rotation positions of the units should be highly correlated, and the candidates should be familiar with the workplace and required skills; the complexity of the work in cross-departmental rotation is higher than that in a single unit. In Japan, work rotation is commonplace, and wholesalersese focuses on the cultivation of all-round talents. Hence, both employees and managers have the opportunity to rotate their work. However, work rotation is extremely difficult, as it involves different professions in different departments (Alex, 2003). Most importantly, SH incorporates technology-oriented strategic positioning in its BPR. Through cross-departmental integration of the business, accounting, storage, delivery, and after-sale service departments, SH recruits employees according to their professional skills related to "electronics, electric work, and electric machinery". In this way, SH has gradually developed the abilities to focus on professional electric maintenance skills (technology-oriented), integrate other departments, and hold mutual support activities among different organizations, i.e. mutual influence between two separate activities, in order to create high-level fit among departmental activities.

According to the abovementioned, the research objective of this study is to explore the development of the strategic BPR model by observing, analyzing, recording, and deducing the evolution of SH, and discuss the adaptability of the model through the case study. The after-sale service of SH dominates process reengineering, and integrates it into strategic positioning to organize key activities, such as cross-organizational and cross-technological department support. Moreover, it creates profits from the idle time of the departments, in order that the organization can take different and practical actions, such as after-BPR labor reduction, without 
reducing its employees. In addition to providing reference and guidance for the future implementation of BPR for small appliance practitioners and other enterprises with similar conditions, this study offers suggestions regarding adjustments to the methods enterprises adopt to undertake service process reengineering, with the hope that enterprises, under the framework of strategic thinking, can enhance organization efficiency and differentiation themselves to sharpen their competitive advantages and achieve permanent operations.

\section{Literature Review}

The study is based on the implementation procedures and methods of process reengineering, as proposed by BPR masters, such as Hammer and Champy (Hammer, 1990; Hammer \& Champy 1993; Lowenthal, 1994; Kettinger, 1997). Starting with the definition and de velopment of the concept of BPR, the author summarizes the types and procedures of BPR, as well as Porter's strategic positioning model, and incorporates the strategic basic elements of positioning, unique activities, trade-offs., and fit into BPR.

\subsection{Enterprise Process Reengineering}

In the Harvard Business Review, Hammer (1990) pointed out that the greatest challenge of the concept of re-engineering was to remove non-value added work, rather than making work automatic through science and technology. From four perspectives - re-position, re-organization, re-system, and re-vitalizing, he argued that enterprises must promote re-engineering; process consists of a series of activities or events that will surely lead to certain expected results. In fact, process is the operation method, work structure, or the logical situation of the development of objects (Weng, 2007). Hammer (2010) reiterated that process was important for enterprises to survive in disorder, and pointed out that the method to finish tasks plays an essential role in the success of enterprises in a world full of drastic changes. To become quicker, better, and more valuable, enterprises must well design their management processes and procedures in all aspects, including marketing, procurement, financial affairs, manufacturing, and after-sale service, in order to reduce costs and increase output. Re-engineering, as put forward by Hammer, is to review the processes of the organization from the perspective of customers, and all departments must make adjustments according to the redesigned process; hence, it is comprehensive reengineering. In addition, Hammer pointed out that BPR is the fundamental re-thinking, as well as the radical processes of work renovation, which aim to attain dramatic improvement in the factors used to measure performance, including cost, quality, service, and speed (Hammer \& Champy, 1993). In activities, enterprises make use of resources to complete a series of rational and relevant tasks to accomplish certain achievements. In general, such a process combination based on the commercial trade system comprises two features - customer-included and cross-organizational (Davenport \& Short, 1990). By adopting BPR, enterprises can make significant improvements and progress in processes within a certain period of time (Frank, 2006). Moreover, they will be able to reduce customer complaints, reaction time, and response errors, and thus, shorten the time for production and service (Tai \& Huang 2007). BPR is basically a philosophy of performance improvement (El Sawy, 2001), and is a promoter of enterprise improvement (Venkatraman, 1994). For the past decade, since being put forward, BPR has created a heated wave of enterprise process improvement.

In short, enterprise processes are intended to achieve different management- or operation-related objectives, and process design reflects managers' views on management; different managers lead according to different management objectives and diverse process designs (Chu, 2010). Great changes to internal and external environments makes it difficult for enterprises to control their existing operations, thus, they must conduct fundamental re-thinking and thorough reforms of the work processes to maintain or reestablish their advantages through the "BPR" project.

\subsection{Procedures of BPR Implementation}

Based on the scope, angle, and angle extension of different industries, scholars have put forward many concepts and ideas about enterprise process innovations that have captivated global attention. After such concepts and ideas were put into practice, they were deeply discussed and followed by enterprises. Against such a backdrop, many methods of process reengineering have come into being, and of all these methods, the four-stage BPR implementation method, as proposed by Hammer (See Figure 1), attracts the greatest attention (Hammer \& Champy, 1993).

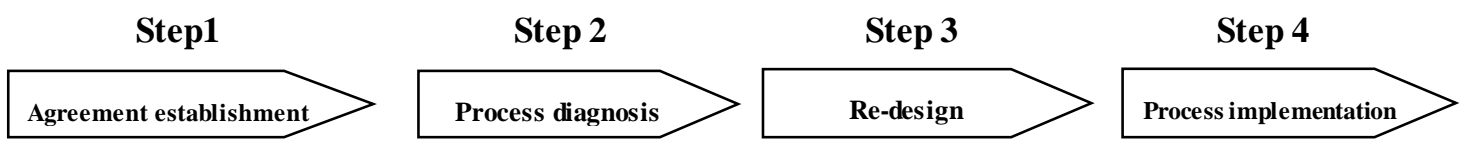

Figure 1. Procedures of BPR Implementation

Source: Hammer and Champy, 1993 


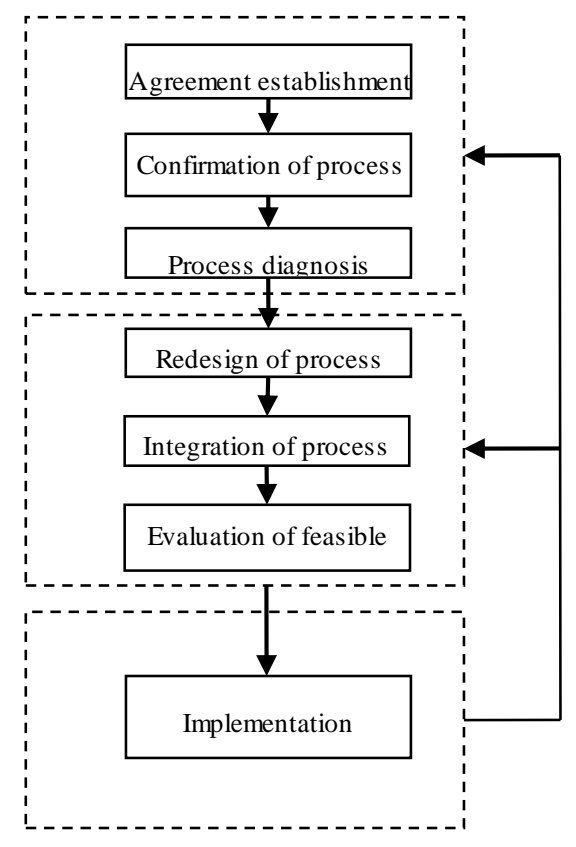

Figure 2. Three Stages of BPR Implementation

The study summarizes the implementation procedures and methods of process reengineering, as proposed by a large number of scholars (Hammer, 1990; Lowenthal, 1994; Kettinger, 1997; Wu, 1999; Harmon, 2007). In general, the main structure of the research procedure and method is divided on the basis of Hammer's four-stage BPR implementation method, as mentioned above; therefore, this study induces the scholars' main procedures and methods of introducing BPR, and puts forward the set of procedures and methods adopted by SH during BPR implementation, which includes three strategic stages and seven steps (See Figure 2), and serve as the analytical basis for the follow-up and strategic positioning integration of this study.

According to previous studies, many scholars regard process reengineering as an effective weapon to confront drastic changes to the environment and to solve crises. However, process reengineering, as advocated by Hammer and Champy (1993), had a success rate of merely 30-50\% and about 50\% of unfulfilled achievements (McNurlin \& Sprague, 1998), as there are few analytical tools for the redesign of actual business processes. According to some universal observations, BPR would not lead to the expected results, as it is a time-consuming and high-cost method with unpredictable results (Limam., Reijers \& Ounnar, 2009). Some doubt that BPR is accurate, and believe that actions must be taken to improve it (Davenport \& Stoddard, 1994), which shows that there are still many problems in BPR-based competitive advantages. Porter (1996), a strategy master, pointed out that BPR can significantly improve or enhance the efficiency of an organization, and that enterprises must adopt strategic positioning to maintain or enhance their competitive advantages to distinguish themselves from their competitors. Only by doing so, he says, can enterprises really stand out in competition. Strategy is a strategic plan based on the trade-offs. of directions. Created by unique and valuable positioning, strategy involves a series of different activities; in the process of making a trade-offs. effective in competition, the nature of strategy is to choose what should not be done and integrate various enterprise activities (Porter, 1998). The author believes that enterprises with complete processes, but without strategic positioning; or those with complete strategic positioning, but without complete processes, will affect their reform. Hence, this study integrates strategic positioning with BPR.

This study uses Porter's positioning development elements, meaning unique activities and trade-offs., to explain the architecture from a horizontal perspective; while the observations of BPR from a vertical perspective are based on the three-stage BPR development model, as summarized in previous studies, they are used to analyze the structure and form of the case in the BPR development stages. Meanwhile, the author combines these two aspects to develop a conceptual structure (See Figure 3). By analyzing the unique activities of process reengineering, and selecting the best fit, as integrated by the mutual support process of the activities in the strategic action system in the case study, this study aims to help enterprises create competitive advantages and a profit-earning model that cannot be imitated by their competitors. 


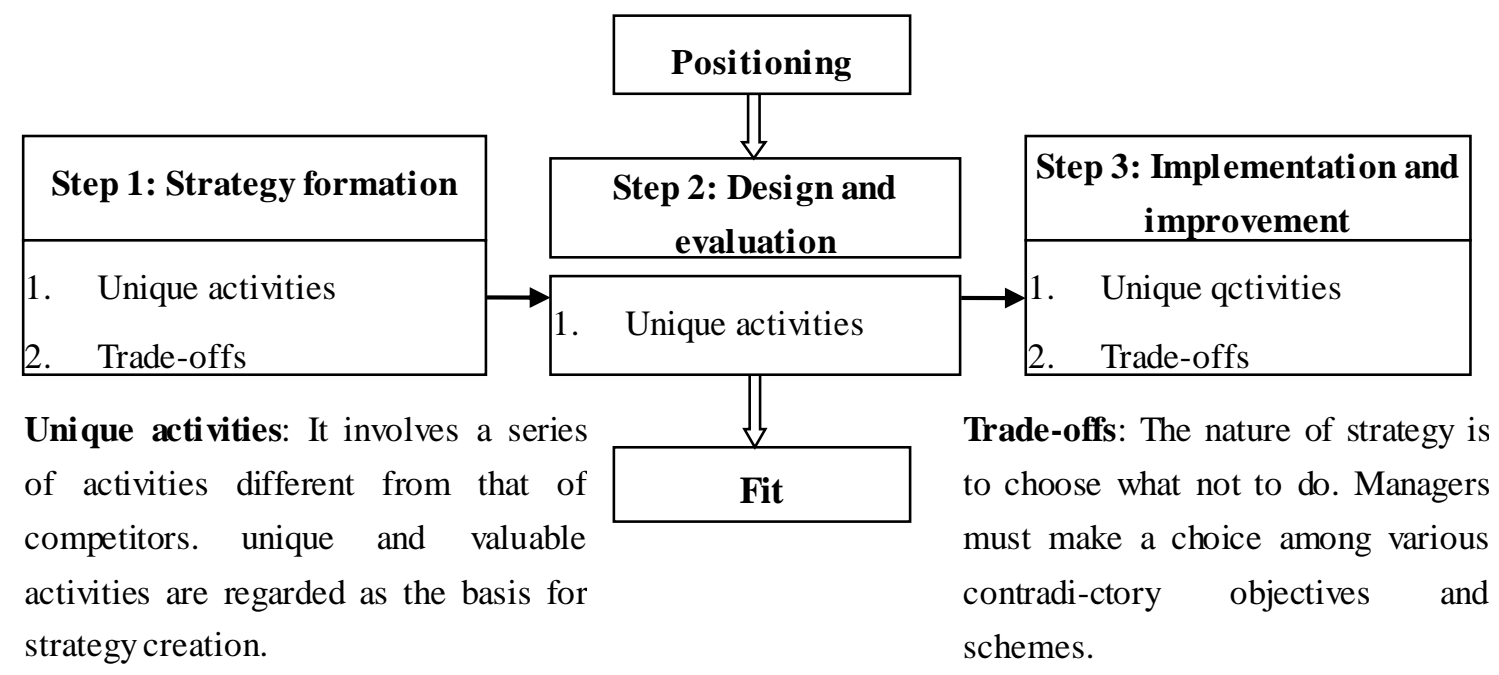

Three-stage Development

Figure 3. Conceptual Framework

\subsubsection{Positioning}

Strategic positioning is the source of uniqueness and serves as the trade-offs of positioning in competition to maintain strategic positioning.

According to the form of the case, this study focuses on the above three roots of enterprise strategic positioning: (1) based on product type: choose the products/service types, rather than enterprises choosing customer groups; (2) based on demand: the services meet the customer needs of most specific groups; (3) based on access: isolate the access channels of customers (Porter, 1996), or adopt some of them, and then, choose and develop the strategic positioning of $\mathrm{SH}$ features.

\subsubsection{Unique Activities and Trade-offs of the Three-stage BPR}

The nature of strategy is to choose what to do, thus, it is necessary to make a trade-offs to maintain consistent positioning. In the case where the development strategy is incorporated into BPR, the development takes on the form and structure that have gradually evolved through the three stages.

1) Step 1: Unique activities and trade-offs in the stage of strategy formation

In the initial stage of implementation, emphasis should be placed on managers' agreement on BPR, the conceptual proposition, and training for employees. When implementing the unique activities and trade-offs. of BPR in this stage, managers would conduct random reviews of the contradictory objectives and schemes to make a trade-offs.; however, design incompatibilities, including excessive or inadequate design, would fracture its value (Porter, 1996). In this case, enterprises must make a trade-offs. among the activities to maintain the consistent direction of positioning.

2) Step 2: Unique activities and trade-offs in the stage of design and evaluation

In the second stage, the external activities of cross-organizational access to customers will be gradually integrated with BPR.

In this stage, strategic positioning covers the demands of internal and external customers, and analyzes the diagnosis of the enterprise's operational processes; moreover, it designs and evaluates the technical tools suitable for enterprises and organizations, and incorporate them through the process of redesign. To connect cross-departmental and cross-organizational activities, the organization constantly holds interpersonal, cross-departmental, and cross-organizational activities, integrates them with the new processes for unique activities and trade-offs., and focuses on the activities that facilitate the company to the outside world. Through development, improvement, and adjustment, it establishes a connection and forms a channel featuring cross-organizational access to customers. Lambert and Cooper (2000) believed that the core enterprise process integration among departments, self-supplies, services, the original manufacturers of information, and ultimate users created comprehensive benefits both inside and outside. 
3) Step 3: Unique activities and trade-offs in the stage of implementation and improvement

The third stage focuses on the final evaluation and makes a trade-offs. regarding the extended unique activities and trade-offs., in order that the organization will be able to introduce technology into cross-departmental and cross-organizational activities, and thus, fulfill the strategic objective of mutual support among activities in the stage. After the three-stage positioning, the original organization, which consists of the separate activities of the departments, gradually de velops into one with unique activities featuring mutual support among departments and interactions with external channel manufacturers. Deriving from technology-oriented talent cultivation, the activities of mutual support among different departments and organizations can reduce the idle time generated from the separate operations of the departments, and thus, reduce costs, due to the "cross" mutual support activities in the final stage of BPR implementation (the 3rd stage in Figure 1). Moreover, they can equip the organization with the competitive advantages that will enable it to beat its competitors in differentiation and cost after the final stage of positioning.

\subsubsection{Fit}

After the design and implementation of the activities that integrated uniqueness and trade-offs. in the three-stage development, the gradual adjustment of the processes of mutual support among some activities turn the mutual influence among the activities into a strategic action system, where the mutual fit among the activities becomes the source of competitive advantages in an intensified manner.

Regarding the significance of fit, the mutual influence among some activities creates strong fit among the activities of different departments. For instance, the improvement of after-sale service will make it easier for the business workers in the business department to negotiate with clients. While the mutual influence among some activities can increase general benefits, there is also a need to include SH in the uniqueness and trade-offs. activities of positioning to form valuable fit. There are three types of valuable fit: (1) consistency among activities; (2) mutual enhancement among activities; (3) mental optimization (porter, 1996), which can be integrated, as they are exclusive to each other. This study chooses the one suitable for SH according to the case, and explores the fit of "mutual enhancement among activities".

\section{Research Method}

To realize the research objective, this study adopts two methods of information collection: (1) participative observations; (2) in-depth interviews with channel clients and competitive peer managers of access service. Due to the issue of the collection of case information, this study chooses $\mathrm{SH}$, a company, which has served the author for over 20 years, and records the important findings of BPR implementation into the observation record, which is the most important source of information.

\subsection{The Participative Observation Method}

One of the authors served SH for 20 years, the author engaged in long-term participation in the formulation of policies regarding business marketing, the distribution of internal human resources, fees for parts, charging standards (channels and consumers), and the after-sale service station. Moreover, the author engaged in communication and coordination with the external channel manufacturers, and thus, became familiar with after-sale service and the details of reform. In the reform of each stage, the author collects, summarizes, and compares the details regarding the operational models, after-sale service guarantees, charging standards, after-sale service routes, service stations, and the home delivery services of competitive peer companies.

\subsection{In-depth Interviews with Channel Members}

Starting from January 2012, this study adopts the convenient interview method to interview the channel practitioners of small appliances (See Table for details about the 77 respondents). Through interviews, the author collects information regarding the needs of channel members in purchasing and after-sale service, as well as information regarding the reform of competitors. The sample selection of respondents is based on diversity and differentiation. In addition, the author made some adjustments to the reference standards of various issues, including business policy, after-sale service outsourcing, proprietary information, participation of channel manufacturers, provision of parts, charging standards for maintenance, acceptable maintenance terms, the demands and charges for home deliveries, and after-sale service satisfaction. Moreover, the interviewer is very familiar with the service operation mechanism. 
Table 1. Respondent

\begin{tabular}{|c|c|c|c|c|c|c|}
\hline \multirow[b]{2}{*}{ Differentiation } & \multirow[b]{2}{*}{ Service unit } & \multicolumn{2}{|c|}{ Channel clients } & \multicolumn{3}{|c|}{ Competitive peers } \\
\hline & & Number & Title & $\begin{array}{l}\text { Service } \\
\text { unit }\end{array}$ & Number & Title \\
\hline \multirow{3}{*}{ Variety store } & Carrefour & 7 & Director \& supervisor & STP & 1 & Manager Chen \\
\hline & RT-MART & 7 & $\begin{array}{c}\text { Manager \& } \\
\text { supervisor }\end{array}$ & TCY & 1 & Manager Chen \\
\hline & Geant A-MART & 6 & $\begin{array}{c}\begin{array}{c}\text { Manager \& } \\
\text { supervisor }\end{array} \\
\end{array}$ & JB & 1 & $\begin{array}{c}\text { General manager } \\
\text { Liu }\end{array}$ \\
\hline Chain & $\begin{array}{l}\text { National } \\
\text { electronics }\end{array}$ & 1 & $\begin{array}{l}\text { Assistant manager } \\
\text { ruan }\end{array}$ & JK & 1 & Manager Chu \\
\hline \multirow{3}{*}{$\begin{array}{l}\text { Wholesaler } \\
\text { Consumer } \\
\text { Interview time }\end{array}$} & Wholesaler & 31 & Owner & SF & 1 & Vise president $\mathrm{Wu}$ \\
\hline & Consumer & 25 & Consumer & & & \\
\hline & From January 201 & Februar & 016 & & & \\
\hline
\end{tabular}

4. Background and Development of the BPR Implementation of SH

Established in 1981, in its initial stage, "SUNHOW(SH)" focused on small appliances, however, with the rise of variety stores in the 1980s. In the 1990s, it entered a stage of vicious and fierce competition, and mainstream channel variety stores followed the trend. In competition featuring the survival of the strong and the elimination of the weak, and the top 3 variety stores - Carrefour, RT-MART, and Geant A-MART, controlled the channel advantages to become the mainstream stores, gradually depriving the channel suppliers of various brands in the small appliance industry of the ability to negotiate price. The cost advantage of Taiwanese enterprises disappeared with Taiwan's entry into the WTO in 2002. Consequently, manufacturers transferred their production lines to Mainland China, resulting in low-priced products of declining quality. As mentioned above, the small appliance industry requires good after-sale service to have the feature of order. In comparison with technology- and service-oriented industries, such as large appliances, computers, and automobiles (See Table 2), the after-sale services of small appliances are large in number and low in charge. High-cost services and operations have always been a difficult issue for the industry to solve; and despite the rapid growth in performance, the significant increase in the cost of after-sale service becomes a heavy burden for manufacturers, which alarms industry operators.

Table 2. Difference between Large and Small Appliance and Computer Industries in After Service

\begin{tabular}{|c|c|c|c|c|c|c|}
\hline Industry & Service manner & Volume & Price & Charge & $\begin{array}{l}\text { Quantity } \\
\text { of sale }\end{array}$ & $\begin{array}{c}\text { Demand on home } \\
\text { delivery }\end{array}$ \\
\hline $\begin{array}{c}\text { Small } \\
\text { appliance }\end{array}$ & $\begin{array}{l}\text { Service center \& } \\
\text { channel station }\end{array}$ & $\begin{array}{l}\text { Medium } \\
\text { and small }\end{array}$ & Low & Low & Huge & Medium \\
\hline $\begin{array}{c}\text { Large } \\
\text { appliance }\end{array}$ & $\begin{array}{l}\text { Service center \& } \\
\text { home delivery }\end{array}$ & Large & High & High transportation fee & Large & High \\
\hline Computer & $\begin{array}{l}\text { Service center \& } \\
\text { home delivery }\end{array}$ & Medium & High & $\begin{array}{c}\text { High Transportation } \\
\text { fee }\end{array}$ & Large & High \\
\hline PS & $\begin{array}{l}\text { The average fee for } \\
\text { large appliance and }\end{array}$ & $\begin{array}{l}\text { ter-sale : } \\
\text { tters } \\
\end{array}$ & & appliance is NT100, wh & the nun & is over NT1,000 for \\
\hline
\end{tabular}

The after-sale service of small appliances usually refers to a series of services after products or services are sold to consumers, including product introduction, delivery, installation, debugging, maintenance, technical training, and home delivery. The after-sale services of the industry include: (1) install and debug products for consumers; (2) provide technical guidance regarding the usage of products, and according to the needs of consumers; (3) guarantee the supply of maintenance parts; (4) provide maintenance service; (5) handle the repair, replacement, and return of products; (6) handle the letters, visits, and questions of consumers. Moreover, service involves collecting consumers' views regarding the quality of products through various methods, and making timely improvements according to the situation (MBAlib, 2017).

Under the influence of the financial storm and economic recession of 2008, To survive in the face of the great pressure caused by business loss, various brands in the small appliance industry reduced employees and salaries, and adopted no-salary vacations. Some even cancelled their after-sale service departments and addressed the crisis with various strategies, such as outsourcing and process reengineering. General Manager Liu of JB stated "In face of a harsh environment, the first step is to reduce expenditures for survival. Specifically, outsourcing service departments can bring the immediate effect of cost reduction and alleviate the pressure caused by business loss. However, all current small appliance outsourcing of companies are self-employed entrepreneurs, who lack a complete service system and scale, and focus all attention on profit. In addition to the limited number of outsourcing by company, the low quality of service has resulted in a declining number of orders from channel clients. Currently, it is the best choice. General Manager Huang in Shanhao, a service outsourcing of company, 
also discussed his problems and measures, "Although the after-sale service of many small appliance brands is outsourced, it is still hard to define the routes of cruise service because of the large number of products and the inability to provide main parts in time. At present, parts and products beyond the maintenance period are listed as priorities in maintenance service. It is not because of technology nor ability, but the too slow supply of parts and the too low subsidies." Also outsourcing their after-sale service, Manager Chan of TCY and Manager He of STP shared a similar view, "Reducing expenditures through outsourcing is indeed a necessary measure. Although the after-sale service is like that of proprietors who try hard to meet customer needs without considering the cost, and although we gradually lose the orders of the traditional channel clients, service outsourcing can temporarily stop current business loss."

General Manager Hsu of SH said, "In the economic recession, when all our competitors took protective measures, it was a good chance for us to improve the company in the market. Providing we improve our after-sale service and continue to meet customer needs, we will get the orders of channel manufacturers. How to reduce the increasing cost of after-sale service is a problem we continue to focus on. Apart from increasing our service efficiency, we can adopt a reform to reduce the cost; on top of success, we need to undertake a reform that is hard to be imitated by our competitors."

In December 2009, the author was asked to establish a reform project team. After collecting suggestions and ideas from the departments at different meetings, and interviewing the channel clients, the author identified the urgent problems to be solved, including: the waste of the idle time of the departments, the unfixed time of after-sale cruise service, the inability to meet customer demands for delivery of repaired after-sale service products within three days, and the ineffective control over the orders of the traditional channel wholesalers and appliance shop, which often circulated among competitors. Assistant Manager Guo and Vice President Zheng voiced their questions during the discussion, "Currently, those manufacturers who have resorted to outsourcing are reducing their employees. Any reform will provoke wide anxiety that productivity will decline prior to reform." Bewildered, General Manager Hsu said after the meeting, "The employees in different departments could imperceptibly improve their marketing abilities by supporting the sales of variety stores, so why can't these departments support the After-sale Service Department or support each other to reduce the idle labor in different departments? We could encourage employees to support the sales of variety stores after work, when there were no adequate numbers of salespeople in the sale period, so why can't we cultivate the employees in terms of after-sale service?" These questions began to ignite SH mental reform, which switched from business orientation to technology orientation.

\section{Research Analysis and Resul ts}

Based on the long-term participative observations of the SH case, the author summaries the interview data and displays the strategic items of BPR implementation (See Figure 4), as follows:

\subsection{Positioning}

After positioning and trade-offs., SH chose to implement strategic BPR and activities different from the after-sale service outsourcing of other small appliance brands, such as STP, TCY, JB, JK, and SF, who are also SH's main competitors, in order to provide unique and valuable combinations. By gradually constructing unique activities and trade-offs. of the three-stage technology-oriented operation. The various unique activities and trade-offs, which took shape in the process aimed to construct separation from the "customer access channel" positioning of competitors, and transformed the traditional business-oriented operation model into technologyand after-sale service-oriented positioning. 


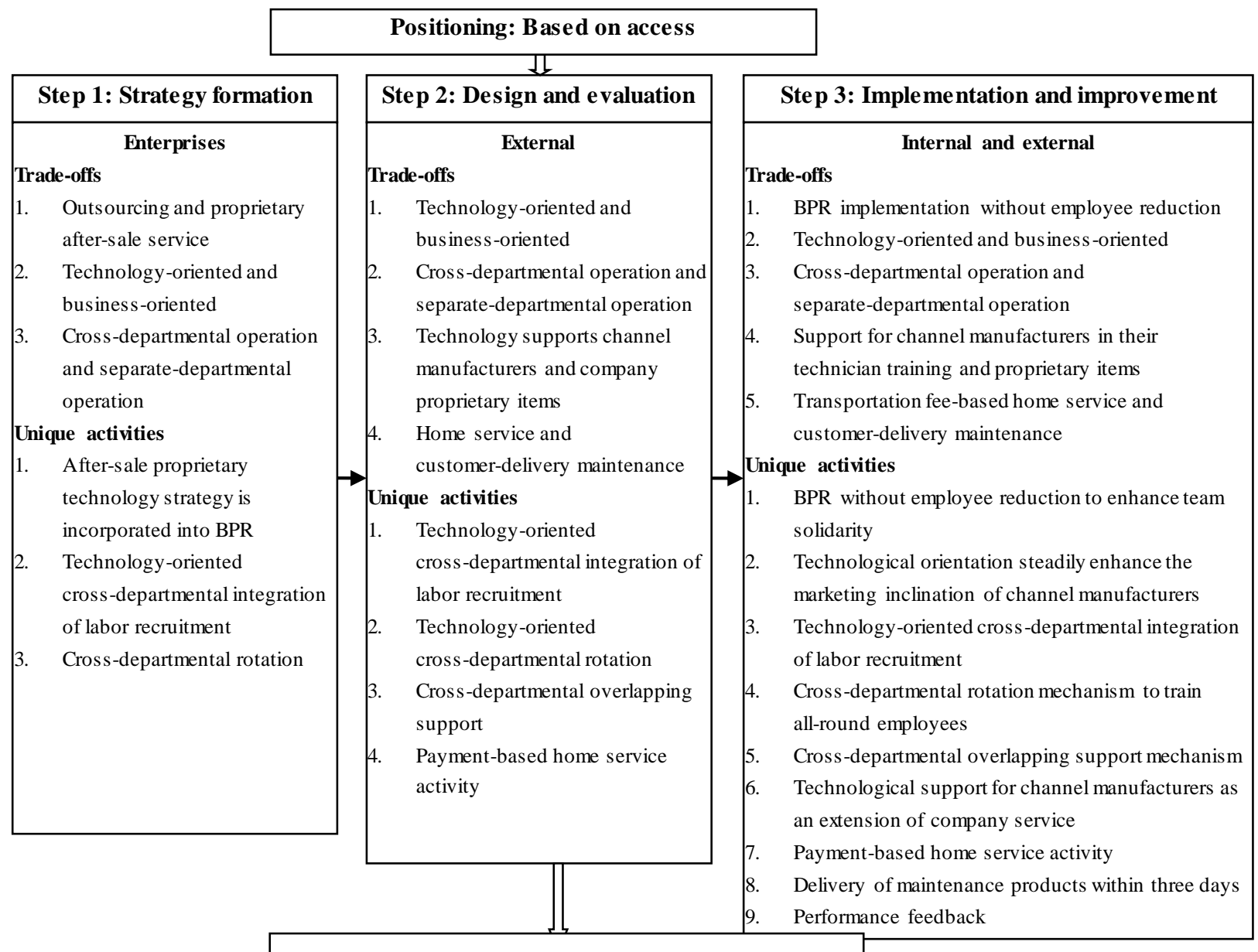

Fit: Mutual enhancement among activities

Figure 4. Strategic BPR Implementation Process of SH

\subsection{Promote the Unique Activities and Trade-offs in the Three Stages of BPR}

\subsubsection{Step 1: Unique Activities and Trade-offs in the Stage of Strategy Formation}

Due to its long-term response to environmental changes, the organization became capable of implementing BPR-integrated strategic positioning. After completing their work, the internal employees in all departments assisted with sales in the stores. To encourage all other departments to help professional technology departments to develop their technology-oriented rotation ability, the SH case developed their cross-departmental rotation ability by recruiting talents with technical strength in the After-sale Service Department and encouraged the Storage and Transportation Department to accumulate experience and ideas, and thus, developed various core capabilities and formed strategies different from that of their peers. After the unique activities and trade-offs., it began to integrate the important starting points of BPR implementation. SH found that its peers began to reduce their employees after they outsourced their after-sale service. To overcome resistance, as caused by the anxiety among the employees in the implementation of reform.

\section{1) Unique activities}

In the development stage of the initial phase of implementation, the following activities were held according to the internal discussions and demands of the channel clients: the implementation of technological orientation and business orientation; the implementation of BPR and after-sale service outsourcing; cross-departmental integration and departmental separate operation. These unique and trade-offs. activities were taken as the basis for development and reform. Finally, after defining the objectives of process and strategic positioning, and undertaking a series of trade-offs. and decision-making activities, SH adopted (1) BPR implementation; (2) technological orientation and cross-departmental integration orientation; (3) cross-departmental and separate-departmental work models. Become an extension of the evaluation and implementation of important strategic positioning in the next stage. 


\section{2) Trade-offs}

After the initial phase of BPR implementation, the complete business objectives and execution strategies of the organization must be presented, and after this stage, SH had clear and key topics for strategic positioning. After the above activities, such as cross-departmental integrated recruitment of talents with professional techniques, the reform concept of strategic BPR took shape. Through communication and coordination, SH gradually established team trust and agreement, confirmed the consistent process objectives of the departments, and incorporated the above unique activities into the process diagnosis to form the actual execution procedure.

\subsubsection{Step 2: Unique Activities and Trade-offs in the Stage of Design and Evaluation}

The unique activities in the initial stage of development were constantly and appropriately promoted in this stage, and the scheme of constructing cross-departmental mutual support was extended. These activities included technology- and business-oriented. After confirming the unique activities projects to be implemented, SH gradually combined strategic positioning activities projects according to the deduction of process objectives, redesigned the processes to be consistent with objective operations, and integrated them. Finally, the SH selected the most feasible scheme as the original version of strategic BPR with scheduled execution.

\section{1) Unique activities}

The unique activities in this stage are based on the strategic objective concepts of technology-oriented operations, which took shape in the early stage of BPR implementation, and are used to evaluate the main items of strategic positioning in the current stage. Finally, the following unique activities factors must be checked: BPR implementation, technology-oriented cross-departmental overlapping support, and payment-based home delivery service. Moreover, unique activities were actually enacted in this stage.

2) Trade-offs.

The trade-offs. in this stage are based on the important factors of strategic positioning, which took shape in the initial phase of BPR implementation in the previous stage. After integrating and extending these ideas into the evaluation of the current stage, the BPR objectives are fulfilled according to the organization, which implemented the listed strategic ideas into the key factors of strategic BPR. After this stage, BPR enters the step of actual implementation.

\subsubsection{Step 3: Unique Activities and Trade-offs in the Stage of Implementation an Improvement}

In the third stage, all possible benefits from the unique activities are measured to make decisions regarding the implementation of BPR without employee reduction, in order to reinforce team solidarity and increase performance feedback. The progress of the implementation of the BPR system is based on constant adjustments and continual improvements that target the final strategic objectives. In the final de velopment stage of BPR, analysis of the changed elements of strategic positioning is, as follows:

\section{1) Unique activities}

After the strategic positioning activities in this stage, BPR implementation without employee reduction is used to enhance team solidarity, technology-oriented cross-organizational support for channel manufacturers, and payment-based home delivery service. These regular and periodic unique activities, as derived from feasibility testing, can gradually increase the influence of mutual support of specialized technologies among different organizations and departments, and gradually facilitate the evaluation of BPR implementation without employee reduction.

\section{2) Trade-offs}

The trade-offs. activities in this stage refer to the selection of strategic positioning schemes in constant contradiction, which includes the removal of the BPR employee reduction mechanism, business-oriented operations, the lack of support for channel manufacturers to train technicians, and other incompatible activities. Here, trade-offs. is based on the interests of the organization, the channel clients, and specialized technology-oriented cross-departmental mutual support. In order to effectively reduce the idle time of some departments and gradually improve the mutual connection mechanism among organizations and departments.

After the strategic positioning activities in this stage, strong executive force is still required to ensure that the unique activities projects can be connected to the process of design. By the end of the third stage of BPR, SH had transformed itself from a concept of strategic positioning into an actual differentiated organization. The switch from business orientation to after-sale service orientation, the cross-department mutual support ability, the cooperation featuring the integration of after-sale service and external channel manufacturers, the steady enhancement of the marketing inclination of channel manufacturers, and the transformation of channel 
manufacturers into an extension of the services of the company, are all the achievements of BPR implementation.

\subsection{Fit - Mutual Enhancement among Activities}

\subsubsection{From Strategic Positioning and Integration to SH's Activities System}

From strategic positioning to integration, SH adopted BPR to accelerate the reception and maintenance of after-sale products. Meanwhile, it collaborated with the external cooperative channel clients of wholesalers business/service, and established overlapping support for the idle labor of the departments, which are the key factors to enhance convenience, increase flexibility, and reduce costs.

The main activities implemented by SH: Increased Access of Service and Service Stations of Channel Manufacturers (IASS), Diverse and Quick Response (DQR), Sharing of Profits and Preferential Price (SPP), Closer Cooperation and Contract-bound Advances from Channel Manufacturers (CBA), Alterative Usage of Cross- Departmental Labor (UCDA), and Intensive Cross-departmental Overlapping Cruise Service (ICDS). Other activities included: Self Delivery for Maintenance, Real-time Pickup and Prior Treatment Service (SDMRTP), Provide Agent Technician Training by Channel Manufacturers (ATCM), Logistic Delivery for Maintenance and Sharing of Fees (LDMSF), Provide Alterative in Case of Failed Delivery within the Planned Period (PAFD), Provide Transportation Fee-based Home Delivery (PTFHD), Provide Support for the Parts of Channel Manufacturers (SPCM), Delivery within Three Days (DTD), Serve Clients through Channel Manufacturers (SCM), Support and Performance Bonuses for Employees (SPBE), Technology- oriented cross-organizational labor recruitment (TCOLR), Comprehensive Talent Cultivation (CTC), Enhance the Usage of Idle Time among Departments(EUITD), Enhance the Marketing Inclination of Channel Manufacturers (EMICM), and Integrate Internal and External Resources (IIER).

These activities supplemented each other, and through the mutual support of the process system (See Figure 5) and the increased efficiency of the After-sale Service Department, the Business Department quickly solved problems regarding after-sale service, which attracted an increasing number of orders and contributed to faster delivery. All such activities created fit among the unique activities, as well as a highly connected activities chain, which is difficult for competitors to imitate (Porter, 1996). The strategic fit features mutually supplemented activities that immediately created competitive advantages and a profit-earning model for $\mathrm{SH}$.

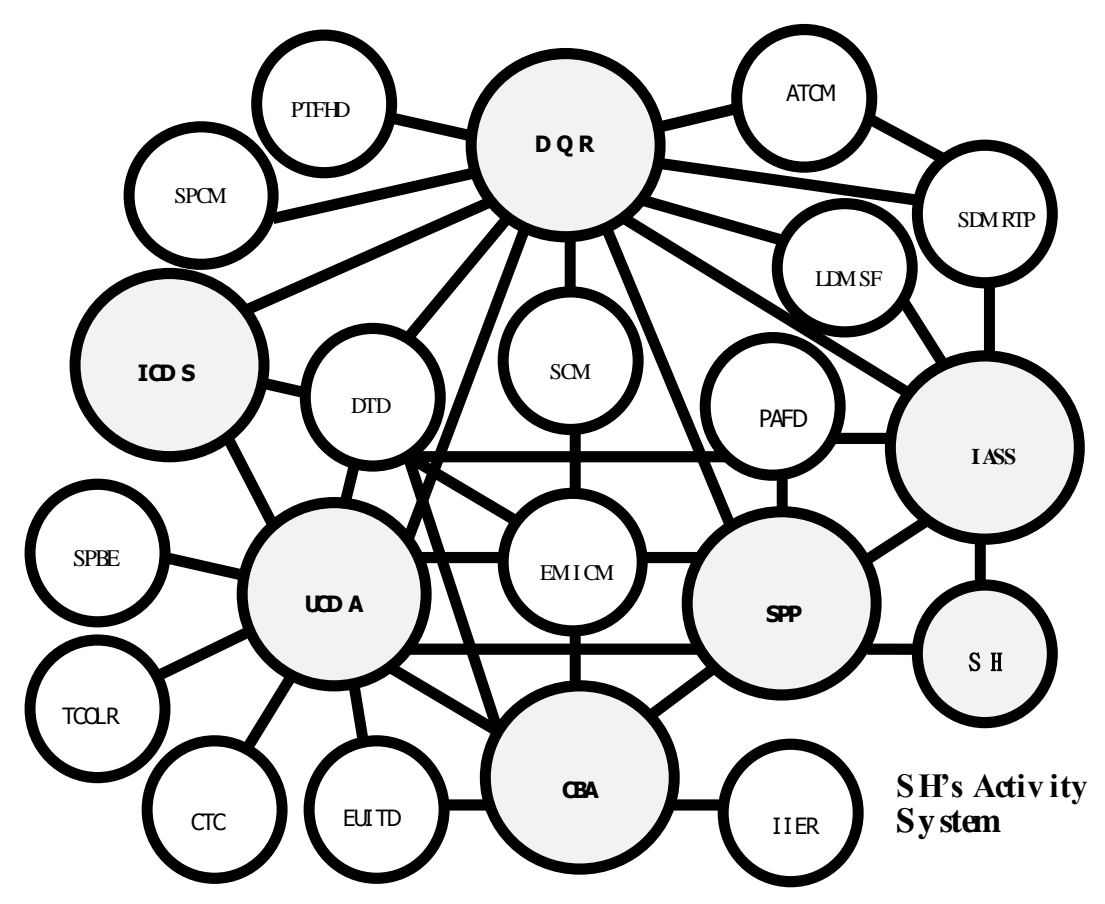

Figure 5. SH's Activities System 


\subsubsection{Fit Constructs an Organization Difficult to Imitate}

Organizations can gain the capital required for labor development, clustered knowledge, skills, capabilities, and other features (KSAOs) (Ployhart, Weekley \& Baughman, 2006). Initially, while the organization may have to pay more to invest in labor, the recovery of the cost includes an increase in productivity, more work for employees, and/or specific knowledge and skills of the organization (Van Iddekinge, Ferris, Perrewé, Blass, \& Heetderks, 2009).

Nowadays, many jobs are mobile, with frequent changes to some duties. In general, organizations tend to recruit those who possess basic abilities, including strong adaption and problem-solving abilities, and can contribute to organizational success in different roles (Lepak \& Snell, 1999). Therefore, SH applied specialized technology-oriented cross-departmental training to develop mutual support abilities in the new cross-department process, which greatly reduced the idle time of its departments. Enterprises have special knowledge and skills to facilitate employees' work, inform employees of their duties, and improve productivity (Hatch \& Dyer, 2004). According to the concept of resource foundation, special knowledge and skills, the experience of training and development, and specific labor capital are most likely to create competitive advantages, as they are valuable, unique, and difficult to imitate.

During BPR implementation, this study explored BPR according to Porter's argument that strategic positioning can increase competitive advantages. In the three-stage development, this study incorporated unique activities and took trade-offs. integration as the strategic action system, in order that the "Fit" could create the mutually supplementary and supportive processes of activities that could constantly generate competitive advantages.

\subsection{Result - Differences and Benefits after the Introduction of BPR}

\subsubsection{Effect of the Introduction Stage - Internal Differences of the SH}

Before the Introduction of BPR

1) Employee reduction during reform caused anxiety among employees

While most peers adopted outsourcing in their reform to quickly reduce costs, the employees became anxious about employee reduction, which seriously affected the operations of the company. In comparison with its peers, the SH case did not reduce its employees during the reform, which significantly reduced the risk of causing anxiety among the staff.

2) The departments were separate and could not support each other

Despite the overlapping business routes of visiting clients, the departments could not assist each other, and thus, quickly failed to meet the needs of clients. If the departments increased their employees, costs would rise; in cross-departmental support and coordination, the limited professionalism of the employees made it difficult to achieve the cross-departmental mutual support process, which led to the separate performances of the departments and rigid operations.

3) The idle time of the departments were not fully used

The operations of the company were based on the separate works of the functional departments. After finishing their work, employees had idle time.

4) The after-sale service departments were regarded as the source of funds

The company focused on the marketing and business departments, which buttressed other departments; in particular, the after-sale service departments were deemed as an endless source of funds.

\section{After the Introduction of BPR}

1) BPR implementation without employee reduction calmed employees

During organizational reform, uncertainties caused resistance from employees. In the initial stage of process reengineering, meetings were held to discuss the approaches and attitude the company should take to solve the crisis; in addition to keeping their employees, the company provided comprehensive training for employees as leaders with business/after-sale service and maintenance skills in the market, and connected cross-departmental support to relieve employees and gain employee support to promote BPR. In comparison, most peers and Wholesalersies in different industries adopted outsourcing and "reduced employees" to decrease costs, which often caused anxiety among employees and affected productivity.

2) Developed the ability to achieve mutual support among different departments

All departments switched their attention from business to technology in labor recruitment. After building a 
foundation of "cross-departmental" rotation, the company "cultivated" their staff in a "comprehensive way", constructed a mechanism featuring an active coordination process with the departments, and achieved mutual support among the departments according to needs. Due to the more "flexible" organizational operation, the departments no longer refused tasks with excuses related to professionalism, which increased the efficiency of internal operations.

3) Idle time was fully used

After the organization implemented BPR, the after-sale service technology-oriented cross-departmental coordination process created a mutual support mechanism. For example, when employees arrived at the office, the directors would provide cross-departmental coordinative support according to the business execution routes of the day. when visiting the clients of channel manufacturers, the Business Department would assist the Service Department transport products for maintenance or assist maintenance on site, thus, the idle time of the departments was adequately used.

\section{4) Low-cost service and quick response}

After integrating BPR with positioning strategies, SH began to develop the ability to achieve cross-departmental technological support. SH answered customers' questions about technology on its website, charged transportation fees for home maintenance service, helped traditional wholesalers construct after-sale service systems, supported technician training, and sold after-sale service parts. All such measures enhanced efficiency through cross-departmental support. Meanwhile, it adopted a clear cross-departmental service route arrangement and cross-departmental labor support process (See Table 3), which significantly increased the participation of the staff, made organizational operations more flexible, and provided rapid response to customers, and thus, reached the goal of reducing costs.

Table 3. After-sale Service Route Arrangement and Cross-departmental Labor Support Process

\begin{tabular}{|c|c|c|c|c|c|c|c|c|}
\hline \multicolumn{2}{|c|}{ Project/Day } & \multicolumn{2}{|c|}{ Monday } & Tuesday & Wednesday & Thurs day & \multicolumn{2}{|c|}{ Friday } \\
\hline & site service & \multicolumn{2}{|c|}{$\mathrm{A}$} & $\mathrm{B}$ & $\mathrm{C}$ & $\mathrm{D}$ & \multicolumn{2}{|c|}{$\mathrm{D}$} \\
\hline Busi & ss department & \multicolumn{2}{|c|}{$\mathrm{B}$} & $\mathrm{C}$ & $\mathrm{D}$ & $\mathrm{D}$ & \multicolumn{2}{|c|}{ A } \\
\hline Deli & ry department & \multicolumn{2}{|c|}{$\mathrm{E}$} & $\mathrm{E}$ & $\mathrm{E}$ & $\mathrm{E}$ & \multicolumn{2}{|c|}{$\mathrm{E}$} \\
\hline Coll & tion and return & \multicolumn{2}{|c|}{$\mathrm{D}$} & $\mathrm{D}$ & A & $\mathrm{B}$ & \multicolumn{2}{|c|}{$\mathrm{C}$} \\
\hline Inte & al maintenance & \multicolumn{2}{|c|}{$\mathrm{D}$} & $\mathrm{A}$ & B & $\mathrm{C}$ & \multicolumn{2}{|c|}{$\mathrm{D}$} \\
\hline \multicolumn{9}{|c|}{$\begin{array}{l}\text { 1. Cross-departmental coordination can be achieved among on-site service, } \\
\text { collection and return, and internal maintenance according to the routes } \\
\text { 2. Channel manufacturers collect maintenance products on Mondays; maintenance } \\
\text { is done on Tuesdays; products are returned on Wednesdays } \\
\text { 3. Provide second-hand alternatives if home service is not finished on the day } \\
\text { 4. Service route codes: Chiayi (A), Changhua (B), Nantou (C), Taichung (D), } \\
\text { order cooperation (E) }\end{array}$} \\
\hline \multicolumn{2}{|c|}{ Brand } & $\begin{array}{c}\text { Manner } \\
\text { of } \\
\text { reform }\end{array}$ & Mind of staff & $\begin{array}{c}\text { Consideration } \\
\text { on operation }\end{array}$ & $\begin{array}{c}\text { Nature of } \\
\text { work }\end{array}$ & $\begin{array}{c}\text { Talent } \\
\text { cultivation }\end{array}$ & $\begin{array}{c}\text { Organization } \\
\text { al operation }\end{array}$ & $\begin{array}{l}\text { Participati } \\
\text { on of staff }\end{array}$ \\
\hline Before & SH & & $\begin{array}{l}\text { Calmed down } \\
\text { employees }\end{array}$ & $\begin{array}{c}\text { Departments were } \\
\text { separate }\end{array}$ & $\begin{array}{l}\text { Business- } \\
\text { oriented }\end{array}$ & $\begin{array}{c}\text { Internal } \\
\text { promotion \& } \\
\text { external } \\
\text { employment }\end{array}$ & Rigid & Middle \\
\hline \multirow{2}{*}{ After } & SH & BPR & $\begin{array}{l}\text { Cross-depart } \\
\text { mental }\end{array}$ & $\begin{array}{l}\text { Cross-departm- } \\
\text { ent coordination }\end{array}$ & $\begin{array}{l}\text { Technolog } \\
\text { y-oriented }\end{array}$ & $\begin{array}{l}\text { Comprehensi } \\
\text { ve \& internal } \\
\text { promotion }\end{array}$ & Flexible & High \\
\hline & $\begin{array}{l}\text { Outsourcing } \\
\text { to peers }\end{array}$ & $\begin{array}{l}\text { Outsourci } \\
\text { ng }\end{array}$ & $\begin{array}{c}\text { Worry about } \\
\text { layoff }\end{array}$ & $\begin{array}{c}\text { Departments were } \\
\text { separate }\end{array}$ & $\begin{array}{l}\text { Business- } \\
\text { oriented }\end{array}$ & $\begin{array}{c}\text { Department } \\
\text { \& external } \\
\text { employment }\end{array}$ & Rigid & Middle \\
\hline
\end{tabular}

5.4.2 Differences among Companies after the Introduction of BPR

Tables 5 and 6 show the differences between SH and its competitive peers in the small appliance industry before and after the reform according to the data collected in observations and interviews. 
Table 5. Differences between SH and Its Peers after the Reform

\begin{tabular}{|c|c|c|c|c|c|c|c|c|c|c|c|c|c|}
\hline Brand Project & \multicolumn{2}{|c|}{ SH (before) } & \multicolumn{2}{|c|}{ SH (after) } & \multicolumn{2}{|c|}{ STP } & TCY & & JB & & JK & \multicolumn{2}{|c|}{ SF } \\
\hline $\begin{array}{l}\text { Method of organiza- } \\
\text { tional sdjustment }\end{array}$ & \multicolumn{2}{|c|}{ Proprietary } & \multicolumn{2}{|c|}{ BPR } & \multicolumn{2}{|c|}{ Outsourcing } & Proprietary & $\mathrm{O}$ & Dutsourcing & Pro & prietary & Outso & urcing \\
\hline $\begin{array}{l}\text { Consideration on } \\
\text { selection strategy }\end{array}$ & \multicolumn{2}{|c|}{ Department } & \multicolumn{2}{|c|}{$\begin{array}{c}\text { Cross- } \\
\text { department }\end{array}$} & \multicolumn{2}{|c|}{ Department } & Department & & Department & Dep & partment & Depa & rtment \\
\hline $\begin{array}{l}\text { Training for } \\
\text { channel technicians }\end{array}$ & \multicolumn{2}{|c|}{ No } & \multicolumn{2}{|c|}{ Yes } & \multicolumn{2}{|c|}{ No } & No & & No & & Yes & & No \\
\hline $\begin{array}{l}\text { Technology for } \\
\text { clients }\end{array}$ & \multicolumn{2}{|c|}{ No } & \multicolumn{2}{|c|}{ Yes } & \multicolumn{2}{|l|}{ No } & No & & No & & No & & No \\
\hline $\begin{array}{l}\text { Cross-departmental } \\
\text { rotation }\end{array}$ & \multicolumn{2}{|c|}{ No } & \multicolumn{2}{|c|}{ Yes } & \multicolumn{2}{|l|}{ No } & No & & No & & No & & No \\
\hline Home service & \multicolumn{2}{|c|}{ No } & \multicolumn{2}{|c|}{$\begin{array}{c}\text { Transportatio } \\
\text { n fee }\end{array}$} & \multicolumn{2}{|l|}{ No } & No & & No & \multicolumn{2}{|c|}{$\begin{array}{l}\text { Large size } \\
\text { charge }\end{array}$} & & No \\
\hline $\begin{array}{l}\text { Channel service } \\
\text { station }\end{array}$ & & $\mathrm{C}, \mathrm{W}$ & All-cha & nnel & $\mathrm{H}, \mathrm{C}$, & & $\mathrm{H}, \mathrm{C}, \mathrm{W}$ & & $\mathrm{H}, \mathrm{C}, \mathrm{W}$ & & $\mathrm{H}, \mathrm{C}, \mathrm{W}$ & $\mathrm{H}$, & $\mathrm{C}, \mathrm{W}$ \\
\hline $\begin{array}{l}\text { Charge of channel } \\
\text { (Discount \% off) }\end{array}$ & $\begin{array}{l}\mathrm{H} 20 / \\
\mathrm{C} 15\end{array}$ & W30/ & $\begin{array}{l}\mathrm{H} 20 / \mathrm{W} 3 \\
\text { C } 15\end{array}$ & & $\begin{array}{l}\mathrm{H} 20 / \mathrm{W} 3 \\
\mathrm{C} 15\end{array}$ & & Charge & & Charge & & Charge & $\mathrm{Ch}$ & $\operatorname{arge}$ \\
\hline $\begin{array}{l}\text { Flexible labor } \\
\text { distribution }\end{array}$ & & No & Yes & & No & & No & & No & & No & & No \\
\hline $\begin{array}{l}\text { Comprehensive } \\
\text { talent cultivation }\end{array}$ & Dep & $\begin{array}{l}\text { rtment } \\
\mathrm{s}\end{array}$ & $\begin{array}{r}\text { Cros } \\
\text { departm }\end{array}$ & $\begin{array}{l}\text { s- } \\
\text { lental }\end{array}$ & $\begin{array}{c}\text { Departm } \\
\mathrm{s}\end{array}$ & nent & $\begin{array}{c}\text { Department } \\
\mathrm{s}\end{array}$ & $\begin{array}{l}\mathrm{D} \\
\mathrm{s}\end{array}$ & Department & & $\begin{array}{l}\text { partment } \\
\mathrm{s}\end{array}$ & Depa & $\begin{array}{l}\text { rtment } \\
s\end{array}$ \\
\hline $\begin{array}{l}\text { External technolo- } \\
\text { gical support }\end{array}$ & & nple & Profess & ional & No & & No & & Simple & & No & & nple \\
\hline $\begin{array}{ll}\text { Days } & \text { for } \\
\text { maintenance } & \end{array}$ & & days & 3 day & & $3 \sim 6 \mathrm{da}$ & & $3 \sim 6$ days & & $4 \sim 6$ days & & 6 days & $3 \sim 6$ & days \\
\hline $\begin{array}{l}\text { Department-oriente } \\
\text { d operation }\end{array}$ & & iness & After se & rvice & Busine & & Business & & Business & & usiness & Bus & iness \\
\hline Labor adjustment & Dep & $\begin{array}{l}\text { rtment } \\
\mathrm{s}\end{array}$ & $\begin{array}{r}\text { Cros: } \\
\text { departm }\end{array}$ & ental & $\begin{array}{l}\text { Employ } \\
\text { reducti }\end{array}$ & & $\begin{array}{c}\text { Department } \\
\mathrm{s}\end{array}$ & & $\begin{array}{l}\text { Employee } \\
\text { reduction }\end{array}$ & & maller & $\mathrm{Sm}$ & aller \\
\hline $\begin{array}{l}\text { Proportion of } \\
\text { channel business }(\%)\end{array}$ & & $\begin{array}{l}72 / \mathrm{C} \\
\mathrm{W} 19 \\
\end{array}$ & $\begin{array}{c}\mathrm{H} 53 / \mathrm{C} 14 \\
3 \\
\end{array}$ & t/W3 & $\begin{array}{r}\mathrm{H} 61 / \mathrm{C} 1 \\
\mathrm{~W} 27 \\
\end{array}$ & & $\begin{array}{c}\text { H67/C15/ } \\
\text { W18 }\end{array}$ & & $\begin{array}{l}\mathrm{H} 72 / \mathrm{C} 10 / \\
\mathrm{W} 18\end{array}$ & & $\begin{array}{l}63 / \mathrm{C} 12 / \\
\mathrm{W} 25\end{array}$ & $\begin{array}{r}\mathrm{H} 70 \\
\mathrm{~W}\end{array}$ & $\begin{array}{l}/ \mathrm{C} 6 / \\
14 \\
\end{array}$ \\
\hline $\begin{array}{c}\text { P S } \\
\text { Table 6. Difference }\end{array}$ & All-c & $\frac{\text { annel cli }}{\text { een Con }}$ & $\begin{array}{l}\text { ents: Hyp } \\
\text { npetitive }\end{array}$ & $\frac{\text { ermarke }}{\text { Peers }}$ & $\frac{\operatorname{ts}(\mathrm{H}) ; \mathrm{Ch}}{\text { after the }}$ & Orgat & $\begin{array}{l}\text { ores }(\mathrm{C}) \text {; Who } \\
\text { anizational }\end{array}$ & $\frac{\text { olesale }}{\text { Char }}$ & $\begin{array}{l}\text { lers (W), Sto } \\
\text { inge }\end{array}$ & ores $(\mathrm{S})$ & & & \\
\hline Brand & & $\mathbf{S}$ & $\mathbf{H}$ & & $\mathbf{T P}$ & & TCY & & JB & JI & $\mathbf{K}$ & SI & $\mathbf{F}$ \\
\hline Reform & & before & after & before & after & before & e after & before & after & before & after & before & after \\
\hline Turnover/ billion $\mathbf{T}$ & & 7.9 & 11 & 12 & 9.8 & 4.7 & 5.4 & 8.3 & 9.5 & 5.1 & 5.7 & 6.3 & 7.9 \\
\hline Business Hyperm & rkets & 70 & 61 & 56 & 72 & 67 & 66 & 72 & 82 & 77 & 73 & 73 & 80 \\
\hline proportion & & 12 & 14 & 13 & 13 & 15 & 15 & 12 & 10 & 13 & 14 & 5 & 6 \\
\hline$\% \quad$ Wholes & alers & 18 & 25 & 31 & 15 & 18 & 19 & 16 & 8 & 10 & 13 & 22 & 14 \\
\hline Service efficiency / & & $3 \sim 6$ & 3 & $3 \sim 6$ & $3 \sim 6$ & $3 \sim 6$ & $3 \sim 6$ & $3 \sim 6$ & $3 \sim 6$ & $3 \sim 6$ & $3 \sim 6$ & $3 \sim 6$ & $3 \sim 6$ \\
\hline
\end{tabular}

5.4.3 Competitive Advantages after the Introduction of BPR

People often mix operation effect with strategy. To improve productivity, quality, and speed, enterprises have created many management tools and technologies, including model learning, outsourcing, BPR, and reform management. Normally, such measures can significantly improve operational effects, for instance, reducing problems in products, and developing better products and services earlier than others (Porter, 1996). Whether enterprises can stand out in competition depends on its activities, such as creation, production, marketing, delivery, and service, which can maintain its advantages. While visiting clients and training staff would initially increase costs, if an enterprise organizes activities that are more effective than that of its competitors, it will gain an vantage in costs. (See Tables 5 and 6). Meanwhile, as SH did not reduce employees during the reform, its showed responsibility for employees, and thus, improved its image. SH organized the above activities different from that of its competitors or similar organizations to create strategic positioning and competitive advantages.

\section{Concl usion and Suggestions}

During BPR implementation by SH, the author also found that the integration concept extended the development and evolution of BPR. Most previous studies concentrated on the role of the BPR model in organization reform; however, BPR alone is far from sufficient to equip an organization with competitive advantages. After selecting the elements of strategic positioning, SH organized unique activities, including BPR implementation without employee reduction, technology-oriented cross-departmental integrated labor recruitment, cross-departmental rotation talent cultivation, and cross-organization support for channel manufacturers to train technicians, which all helped SH construct cross-departmental and cross-organization mutual support processes, make full use of the idle time of the departments, and significantly reduced their operational costs. Additionally, they helped enhance 
service efficiency, gradually regained the orders of lost channel manufacturers, and equipped SH with competitive advantages that are difficult to imitate.

The theoretical and practical significance of this study is, as follows: This study conducts in-depth discussions on the theoretical meaning of BPR, and shares a critical view with other integrated studies on strategic positioning, thus, deepening the understanding of strategic positioning and easing the lack of analysis of strategic positioning factors in the current industry. The mutual support process of unique activities is used to build a connection between external channel manufacturers and the various departments, such as the after-sale service department, the business department, and the storage and transportation department. These activities are mutually supplementary to form fit. A higher-level fit will bring more orders, quicker delivery and after-safe service response, and higher organizational performance (Lawrence \& Lorsch,1969), which will create a highly connected activity chain that is difficult to imitate (Porter, 1996). Practically, relevant technology-oriented operations in Taiwan and overseas, as well as experience in the promotion of automobile and computer projects, all show the high value of after-sale service in promoting technology- and service-oriented operations. However, as average works do not involve activities of specialized technology, cross-departmental rotation is very easy. If different specialized technologies are involved, cross-departmental rotation would be extremely difficult. Regarding three-stage strategic positioning, there must be long-term cross-departmental training and planning strategies that involve specialized technologies, adopt gradual cultivation, adjust various strategies to improve the process, and then, make trade-offs. to fulfill the ultimate objective of positioning. In industries that solve the issue of low operational value of after-sale services, managers must focus on technology for the integration of cross-departmental talent recruitment, in order to create positive influence on the rotation process of cross-departmental mutual support. An increasing number of enterprises are adopting reform to reduce costs without reducing employees, and thus, are maintaining their social responsibility, in order to achieve what would never have been attained through traditional reform. Therefore, providing different strategic positions during BPR observations, as well as different, more effective technology-oriented operation mechanisms, will create more value than depending only on the traditional operation based high value of after-sale service. The author suggests that small appliance manufactures in Taiwan should promote organizational reform, rather than reducing employees to reduce costs, in face of reform and development.

There are three limitations to this study. First, this study adopts the participative observation method for the case study, without comparing the case with other peer cases; in addition it includes research representativeness or prejudice, and lacks the basis for popularization of the differences between phenomenon and theory (Douglas, 1985). Second, although the author had many interviews with the partners and competitors of the case company, some explanations regarding BPR development may not be found in this study, which is the biggest limitation on the exploration into BPR-related topics. Third, while the author attempted to gain the best evidence through participative observations, the process was still imperfect. The analyzed events would attract different views due to different roles and positions, thus, it is difficult to achieve completely correct results. Therefore, future studies are suggested to increase the number of cases and identify the operational problems of enterprises from the perspective of the integration of BPR with strategic positioning. The author believes that this suggestion will deepen public comprehension of the formation and e volution of strategic BPR. Moreover, future researchers can obtain sufficient evidence and support through direct participative observations over a longer period.

\section{References}

Alex, H. (2003, May 31). Workplace competitiveness, job rotation, leaving an alternative. Cheer magazine Retrieved from http://www.cheers.com.tw/article/article.action?id=5024921

Baidu Data Research Center. (2017). Home appliance analysis -The Small appliance. Retrieved from http://data.baidu.com/jiadian/jiadian5/part9.html

Bennett. (2003). Training Strategies for Tomorrow. Bradford, 17(4), 7.

Cascio, W. F. (2002). Strategies for responsible restructuring. Academy of Management Executive, 16(3), 80-91. https://doi.org/10.5465/AME.2002.8540331

Champy, J. (1995). Reengineering Management: The Mandate for New Leadership. Harpe Bessusin, New York.

Chang, H. Y. (2011, October Issue). Three Worst Situations of the European Debt Crisis. Common Wealth Magazine, 482.

Chang, Y. L. (2005). Study on the Relationship among Competitiveness, Competition Strategy and Operation Performance in the Taiwanese Appliance Industry (Unpublished master's Thesis), University of Yu Da, Miaoli, Taiwan. 
Chen, C. S., \& Hsia, J. W. (2001). Human resources management organizational downsizing, the Asia-Pacific Education and Training Network. Retrieved from http://carryshen.tripod.com/content_hr4.htm

Chen, C. Y. (2010). Analysis of the Current Situation of the Taiwanese Appliance Industry. Metal Center Industry Research Team, Appliance Industry Monthly report.

Chen, G. H. (2012). Analysis of the Competitiveness of Taiwan, Wholesalers and South Korea in the Appliance Industry. (Unpublished master's Thesis) University of Fu Jen Catholic, New Taipei, Taiwan.

Chuang, C. Y. (2009). Case Study on the Competition Strategies of Taiwan Appliance Manufacturers under the Cross-strait ECFA. (Unpublished master's Thesis) University of National Science and Technology, Taipei, Taiwan.

Chu, J. M. (2010). Study on the Analytical Methods of Enterprise Process. (Unpublished master's Thesis). University of National Sun Yat-sen, Kaohsiung, Taiwan.

Davenport, T. H., \& Short, J. E. (1990).The New Industrial Engineering : Information Technology and Business Process Redesign. Sloan Management Review, 31(4), 11-27.

Davenport, T. H., \& Stoddard, D. B. (1994). Reengineering: Business Change of Mythic Proportions? MIS Quarterly, 121-127. https://doi.org/10.2307/249760

Douglas, J. D. (1985). Creative Interviewing. California, CA: Sage.

El Sawy, O. A. (2001). Redesigning Enterprise Processes for e-Business. New. York, NY: McGraw-Hill.

Fisher S. R., \& White M. A. (2000). Downsizing in a learning organization: Are there hidden cost? Academy of Management Review, 25(1), 224-251. https://doi.org/10.2307/259273

Frank, U. (2006). Improving Shared Service Implementation: Adopting Lessons From the BPR Movement. Business Process Management Journal, 12(2), 191-205. https://doi.org/10.1108/14637150610657530

Hammer, M. (1990). Reengineering Work: Don’t Automate, Obliterat. Havard Business Review, 68(4), 104-112.

Hammer, M., \& Champy, J. A. (1993). Reengineering the Corporation: A Manifesto for Business Revolution. New. York, NY: Harper Collins. https://doi.org/10.1016/s0007-6813(05)80064-3

Hammer, M., Hershman, L. W., \& Wilson, G. K. (2010). Faster Cheaper Better - The 9 Levers for Transforming How Work Gets Done. New York, NY: Crown Business.

Hatch, N. W., \& Dyer, J. H. (2004). Human Capital and Learning as a Source of Sustainable Competitive Advantage. Strategic Management Journal, 25, 1155-1178. https://doi.org/10.1002/smj.421

Harmon, P. (2007). Business Process Change: A Manager's Guide to Improving, Redesigning, and Automating processes. (2nd ed.).. San Francisco, SF: Morgan Kaufmann.

Kettinger, W. J. (1997). Pragmatic Perspectives On The Measurement of Information Systems Service Quality. MIS Quarterly. https://doi.org/10.2307/249421

Lambert, D. M., \& Cooper, M. C. (2000). Issues in Supply Chain Management. Industrial Marketing Management, 29(1), 65-83. https://doi.org/10.1016/S0019-8501(99)00113-3

Lawrence, P. R., \& Lorsch, J. W. (1969). Developing Organizations: Diagnosis and Action. Reading, Mass: Addision-Wesley Publishing, 23-30.

Lepak, D. P., \& Snell, S. A. (1999). The Human Resource Architecture: Toward a Theory of Human Capital Allocation and Development. Academy of Management Review, 24,31-48.

Limam, M. S., Reijers, H. A., \& Ounnar, F. (2009). Development of a Decision-Making Strategy to Improve the Efficiency of BPR. Expert Systems with Applications, 36(2), 3248-3262, 41(1).

Lin, W. J. (2014). Traditional Industries Project tutoring industry - Industry Overview and import and export analysis (Small appliance and yacht). Metal Industries Research \& Development Centre. http://www.slideshare.net/mirdc/20141023-42289535

Lowenthal, J. N. (1994). Reengineering the Organisation: A Step-by-Step Approach to Corporate Revitalization. Quality Management Journal, 1(3), 57-79.

MBAlib. (2017). After sales service. Retrieved http://wiki.mbalib.com/zh-tw/\%E5\%94\%AE\%E5\%90\%8E\%E6\%9C\%8D\%E5\%8A\%A1

Mckee Ryan, F. M., \& Kinicki, A. J. (2002). Coping job loss: a life-facet perspective. International Review of 
Industrial and Organizational Psychology, 17(1), 1-29. https://doi.org/10.1002/9780470696392.ch1

McKinley, W., Sanchez, C. M., \& Schick, A. G. (1995). Organizational downsizing : constraining, cloning, learning. Academy of Management Executive, 9(3), 32-44. https://doi.org/10.5465/ame.1995.9509210276

McNurlin, B. C., \& Sprague, Jr. R. H. (1998). Information Systems Management in Practice. (7th, ed.). New Jersey, NJ: Prentice-Hall.

Ployhart, R. E., Weekley, J. A., \& Baughman, K. (2006).The Structure and Function of Human Capital Emergence: A Multilevel Examination of The Attraction-Selection - Attrition Model. Academy of Management Journal, 49, 661-677. https://doi.org/10.5465/AMJ.2006.22083023

Porter, M. E. (1996).What is Strategy. Harvard Business Review, 74(6), 61-78.

Porter, M.E. (1998).On Competition. Boston, BOS: Harvard Business School Press.

Shah, P. P. (2000). Network destruction: The structural implications of downsizing. Academy of Management Journal, 43(1), 101-112. https://doi.org/10.2307/1556389

Sun, B. T. (1994). Study on the Implementation Strategy and Influence of Organization Restructuring, Personnel Monthly, 19(3), 30-36.

Tai, W. S., \& Huang, C. E. (2007). The Relationship Between Electronic Business Process Reengineering and Organizational Performance in Taiwan. The Journal of American Academy of Business, Cambridge, 10(2), 296-301.

Tan, S. C. (2008). Association of Small and Medium Enterprises: 7,000 Small and Medium Enterprises Go Bankrupt Each Month. Taipei, TP: Commercial Times.

Tenner, A. R., \& DeToro, I. J. (1997). Process Redesign : The Implementation Guide for Managers. Boston, BOS: Addison Wesley.

Tsai, C. C. (2004). The Operation Positioning of Taiwanese Manufacturers - Based on the Development of the Appliance Industry in Major Countries. Industrial Technology Research Institute IEK Systematic Energy Team. ITRIEK-0453-S216(92).

Van Iddekinge C. H., Ferris G. R., Perrewé P. L., Blass F. R., \& Heetderks T. D. (2009). Effects of Selection and Training on Unit-Level Performance Over Time: ALatent Growth Modeling Approach. Journal of Applied Psychology, 94, 829-832. https://doi.org/10.1037/a0014453

Venkatraman, N. (1994). IT -Enabled Business Transformation From Automation to Business Scope Redefinition. Sloan Management Review, Winter, 73-88.

Weng, D. C. (2007). Skills for Enterprise Process Management. Taipei, TP: Xianye Enterprise Management Consulting Co., Ltd..

Wu, K. L. (1999). Drawing of Process Charts and Process Reengineering. Taipei, TP: Ruilin Enterprise Management Consulting Co., Ltd.

\section{Copyrights}

Copyright for this article is retained by the author(s), with first publication rights granted to the journal.

This is an open-access article distributed under the terms and conditions of the Creative Commons Attribution license (http://creativecommons.org/licenses/by/4.0/). 